\title{
Dairy Trade in Ethiopia: Current Scenario and Way Forward-Review
}

\author{
Gezu Tadesse ${ }^{1 *}$ and Zelalem Yilma ${ }^{2}$ \\ ${ }^{1}$ Wachemo University Department of Animal Science, Ethiopia \\ ${ }^{2}$ Addis Ababa, Ethiopia
}

Submission: October 06, 2018; Published: October 25, 2018

*Corresponding author: Gezu Tadesse, 1Wachemo University Department of Animal Science, Ethiopia, Tel: 510910969.7 ; Email: gezutadesse@gmail.com

\section{Abstract}

This review is concern on dairy trade in Ethiopia, current scenario and way forwards for enhancing dairy investment of Ethiopia. Consumers in Ethiopia come to be through formal and informal marketing system. The country spent over 678.75 million birrs to import various products of milk from 2006-2010 and the expenditure for powdered milk accounted for $79.6 \%$, followed by cream, $12.9 \%$ and cheese $4.3 \%$. Milk and its products market have changed significantly with strong global growth stemming in from the presence of evermore consumers in developing countries. To achieve the demand of milk and milk products in Ethiopia, it should be improve the genetic potential of dairy animal/cow- this could be through put in on genetic improvement on dairy animals, encouraging forage and fodder production and trade, establish agro-processing oil crops and use of by-products for animal feed, improving the productive, reproductive and weight gain performance of crossbreds, through enhanced provision of animal health services and better feed.

Keywords: Dairy Trade; Development policy; Milk market

Abbreviations: WTO: World Trade Organization; DDA: Dairy Development Agency; NFDM: Nonfat Dry Milk; DDE: Dairy Development Enterprise; DMY: Daily Milk Yield; WMP: Whole Milk Powder; SMP: Skim Milk Powder; GATT: General Agreement on Tariffs and Trade negotiations; LOD: Limit Of Determination; HACCP: Hazard Analysis Critical Control Point; DDMP: Dairy Development Master Plan; ADLI: Agriculture Development Led Industrialization; PRSP: Poverty Reduction Strategy Program; FSS: Food Security Strategy; RDPS: Rural Development Policy and Strategies; CBSP: Capacity Building Strategy and Program; AMS: Agricultural Marketing Strategies; IFD: Improved Family Dairy; BDS: Business Development Services

\section{Introduction}

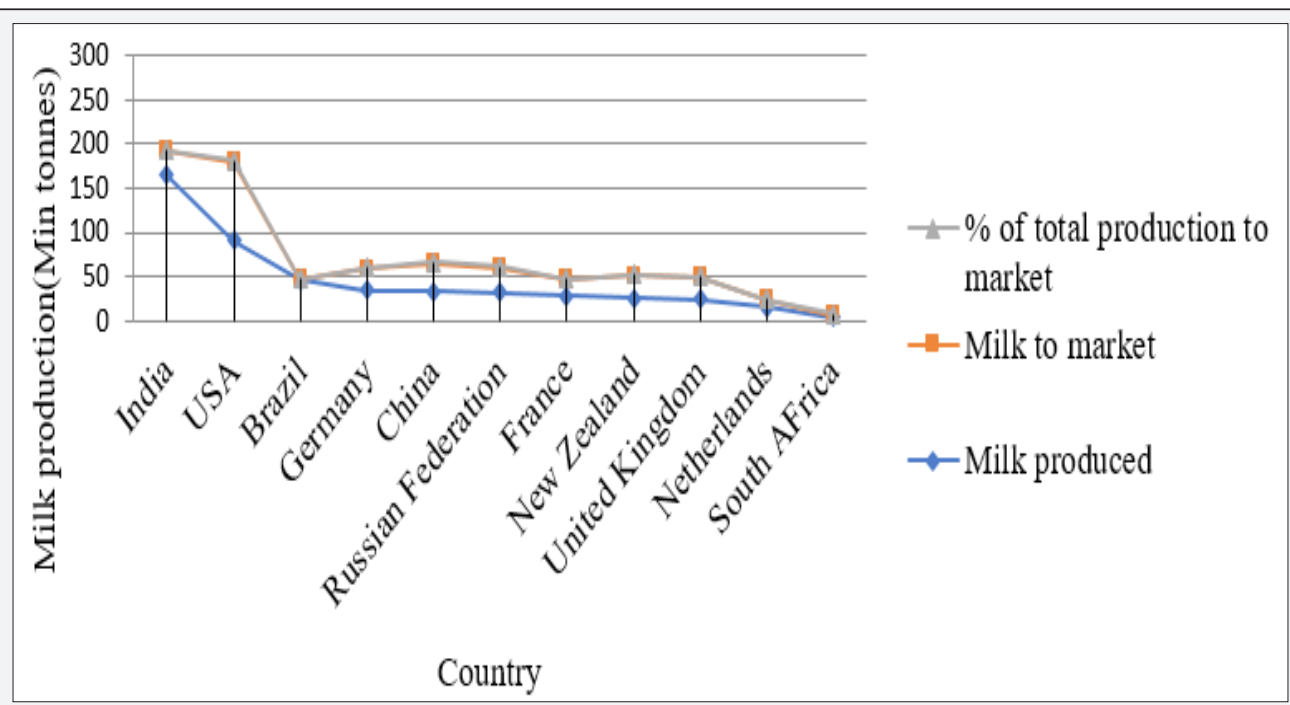

Figure 1: Milk production for the top 10 milk-producing countries and South Africa.

World trade in dairy products has grown in recent decades at rates that generally exceed demand growth in developed countries which produce most the world's dairy products [1]. In the world total milk production and trade is 816.0 and 73.2 million tones, respectively [2] (Figure 1). Milk and dairy products market have changed significantly with strong global growth stemming from 
the presence of evermore consumers in developing countries. The statistics showed a process of industrialization in the dairy chain with the marked presence of large national companies developing on the international scene and which also tend to concentrate the market [3]. Total world dairy exports grew by $4.6 \%$ per year on a milk equivalent basis during 2010-2014 [1] and the milk production also grew up $2.4 \%$ in 2014 a rate like previous years reaching 792 million tons. This is related with a favorable milk production outlook in most of the major exporting countries and continuous strong demand [4].

Ethiopia has one of the largest livestock inventories in Africa with a national herd estimated cattle population in Ethiopia is about 57.83 million, 28.04 million sheep, 28.61 million goats, 1.23 million camel and 60.51 million poultry. Out of 57.83 million cattle the female cattle constitute about $55.38 \%$ (32.0 million) and the remaining $44.55 \%$ (25.8 million) are male cattle. From the total cattle in the country $98.59 \%$ (57.01million) are local breeds and remaining are hybrid and exotic breeds that accounted for about $1.19 \%(706,793)$ and $0.14 \%(109,733)$, respectively [5]. Ethiopia holds large potential for dairy development particularly Ethiopian highlands possess a high potential for with diverse topographic and climatic conditions favorable for dairying [6]. Smallholder dairy farms in Ethiopia particularly in regional and zonal cities are alarmingly increasing because of high demand of milk and milk product from resident. However, the existing farming system which holds maximum of 10 or 15 cows per individual is not satisfactory to fulfill the demand. In addition, farming system has a major problem with regards to feed source, feed supply and the amount given per animal below the minimum standard, which entails in reduction in production and reproduction in the Dairy Trade Development in World farms [7]. Livestock play a vital role in economic development; particularly as societies evolve from subsistence agriculture into cash-based economies [8]. Livestock in Ethiopia perform important functions in the livelihoods of farm owners, pastoralists and agro-pastoralists.

Dairy products in Ethiopia are channeled to consumers through formal and informal marketing systems [9]. The formal marketing system appeared to be expanding during the last decade with private farms entering the dairy processing. The informal market directly delivers dairy products by producers to consumer (immediate neighborhood or sales to itinerant traders or individuals in nearby towns). Generally, the low marketability of milk and milk products pose limitations on possibilities of exploring distant but rewarding markets. Therefore, improving position of dairy farmers to actively engage in markets and improve traditional processing techniques are important dairy value chain challenges of the country [10]. To develop dairy production system of Ethiopia, dairy supply and marketing system needs to undertake radical changes. To get access to distant markets farmers need to link up with manufacturers able to extend the shelf-life of farmers' supply, as well as with traders and retailers, which can ensure a capillary distribution of final products. In short, dairy products cannot be expected to flow across Ethiopia unless a supply chain, bridging rural supply and urban demand is in place [6]. The country has not supplied the demand of milk and milk products because of different problem. To solve the problem or to increase the production of milk it should be focused on the policy and trade. Therefore, the objective of this review is to discuss on dairy trade in Ethiopia, current scenario and way forwards for enhancing dairy investment of Ethiopia.

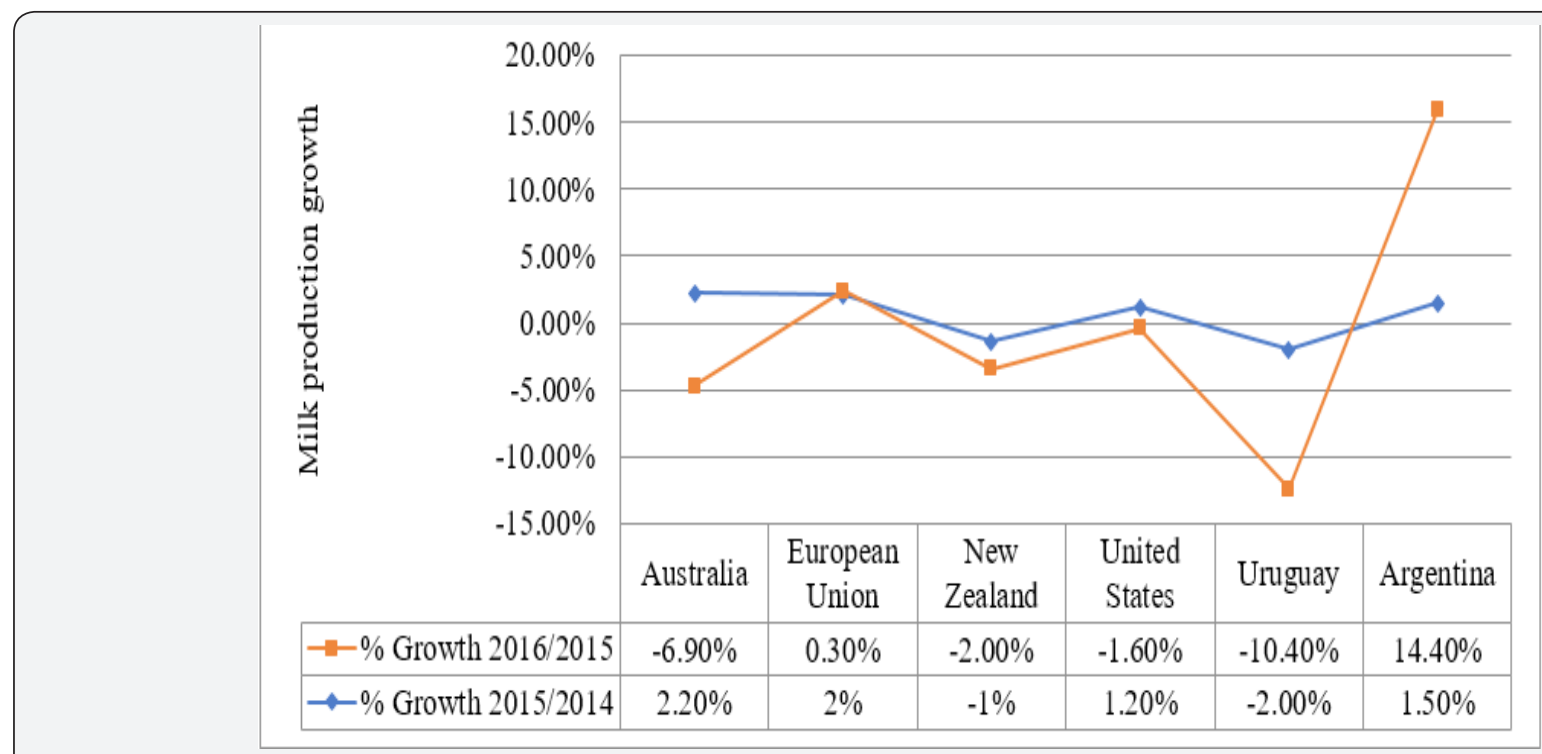

Figure 2: Milk production growth: 2015 compared to 2014, and 2016 compared to 2015 selected countries.

Global dairy consumption has been on the rise steadily since 2005 except for 2009 and 2015. Trade in a large quantity (46\%) of milk is informal [11] through short supply chains, and even with the formal trade most milk does not cross currency borders.
The main reason dairy trade fell in 2009 was due to the global financial crisis. In 2015, dairy trade dropped by weaker demand for dairy commodities. The export subsidies received by European Union's dairy farmers from their government contributed to 
lower international dairy prices and a weaker demand for dairy commodities (Figure 2). The increase in Europe's dairy production grew faster than consumption. Dairy imports grew in value from $\$ 15$ billion in 2005 to $\$ 43.2$ billion in 2014, a $187 \%$ increase in US dollars. Similarly, global dairy exports expanded $175 \%$ in value from 2005 to 2014. The leading dairy importers from 2005 to 2009 were the United States, Mexico, Japan, Russia, and the European Union-28. From 2010 to 2015, the situation changed as China emerged as the world's largest dairy importer followed by Russia, the US, Mexico, and Japan. Although the demographic landscapes of dairy consumption are changing globally, the major suppliers of dairy commodities have remained relatively unchanged from 2005 to 2015. New Zealand is the world's largest dairy exporter in terms of volume. The four top global dairy exporters during the observed period based on value are the EU-28, New Zealand, the US, and Australia [12].

Over the last decade, interest in global dairy trade has intensified partially because of the enormous impact that domestic and international policies have had or are projected to have on the global trade and domestic supply. One significant example in the negotiations is the proposal made by the world trade organization (WTO) during the Nairobi ministerial in December 2015 in effort to help stabilize world dairy prices by eliminating export subsidies over the next four years. While many dairy commodities are traded internationally, some of the largest global exchanges involve cheese, nonfat dry milk (including skim dry milk), whey, and butter. In 2015 these four commodities accounted for 50\% of the total value of global dairy imports. Of all the dairy commodities imported globally in 2015 , cheese accounted for $24 \%$ of the total value [13].

Global dairy demand is estimated at approximately 15 million tons of product annually. The top 5 are China, Russia, Mexico, Japan and the USA. The US is the only major importer that is also a major net exporter. China imports $\sim 2$ million tons of dairy products annually, Russia $\sim 1.4$ million tons, Mexico and Japan over 500 thousand tons each. In addition, the US, Indonesia, Philippines, Saudi Arabia and Algeria import over 400 thousand tons and Singapore, Iraq, Malaysia, Venezuela and UAE importing over 300 thousand tons annually. Ethiopia exported an amount less than 300,000 USD per annum during the last five years. Majority of the export destined to Somalia and traditional spiced butter export for Ethiopian community and other consumers to USA and other countries. With the expansion of the sector the volume exported to Somalia can be increased and to other destinations like Sudan, South Sudan and Djibouti can be expanded. Nonfat dry milk (NFDM) was the second largest (in value) dairy commodity imported making up $11 \%$ of the world's total dairy imports in 2015. The import value of NFDM grew by $96 \%$ from 2010 to 2014 and the top importers in 2015 included Mexico, China, Indonesia, and Malaysia. Whey and butter were the third and fourth largest dairy commodities imported, respectively. Both whey and butter balanced out at $7 \%$ of the total value of dairy imported in 2015. Over the five-year span from 2010 to 2014 the value of global imports of whey and butter increased by $81 \%$ and $62 \%$, respectively. The world's leading importers of whey are China, the US, and Indonesia, while Russia, Iran, and China are the leading importers of butter [14].

\section{Dairy Production Development History in Ethiopia}

Before started formal dairy production in early 1950s, dairy production in Ethiopia in the first half of $20^{\text {th }}$ century was mostly traditional [2]. In 1947 the country has received 300 Friesian and Brown Swiss dairy cattle as a donation from the United Nations Relief and Rehabilitation Administration [15] to attempt the modern dairy production. With the introduction of these cattle in the country, commercial liquid milk production started on large farms in Addis Ababa and Asmera [16] and a small milk processing plant was established in Addis Ababa to support commercial dairy production [17]. During the second half of 1960s, dairy production around Addis Ababa began to develop rapidly due to demand and large private dairy farms and collection of milk from dairy farmers [2]. In 1971 Government established dairy development agency (DDA) to control and organize the collection, processing and distribution of locally produced milk, and facilitated the creation of dairy cooperatives to ease the provision of credit and technical and extension service to dairy producers [6]. Distribution of exotic dairy cattle particularly Holstein Friesian was done through government owned large-scale production such as WADU, ARDU and CADU. These units produced and distributed crossbred heifers, provided AI services and animal health service, in addition to forage production and marketing [18]. To establish the dairy development enterprise (DDE) numerous nationalized dairy farms (include large dairy farms, milk collection networks, and a processing plant) was merged in 1979 [17]. Distribution of exotic dairy cattle particularly Holstein Friesian was done through government owned large-scale production such as WADU, ARDU and CADU. These units produced and distributed crossbred heifers, provided AI services and animal health service, in addition to forage production and marketing [18]. The development of dairy sub sector is the shared effort of all stakeholders that explicitly and implicitly participate in the different activities of dairy development [19].

Currently, to bring market-oriented economic system, private sector begun to enter the dairy sector and market as an important actor the country's policy reform. Many private investors have established small and large dairy farms. This commercial farm use grade and crossbred animals that have the potential to produce 1120-2500 litres over 279-day lactation. This production system is now expanding in the highlands among mixed crop-livestock farmers, such as those found in Selale, Ada'a and Holetta, and serves as the major milk supplier to the urban market. Additionally, some ten private investors and one cooperative union have established milk-processing plants to supply fresh processed milk and dairy products to Addis Ababa, Dire Dawa and Dessie towns. Most interventions during this period was focused on urban-based production and marketing. During the second half of the 1960s dairy production in the Addis Ababa area began to develop rapidly because of the expansion in large private dairy farms and the participation of smallholder producers [6]. 


\section{Dairy Production Systems in Ethiopia}

Dairy production is practiced almost all over Ethiopia involving a vast number of small subsistence and marketoriented farms [20,21], and is being practiced as an integral part of agricultural activities in Ethiopia since a time of immemorial. There are different types of milk production systems identified based on various criteria [22]. Based on climate, land holdings and integration with crop production as criterion, the dairy production system classified as rural (pastoralism, agro-pastoralism and highland mixed smallholder), peri-urban and urban [9,20,21,23]. The dairy sector in Ethiopia can also be categorized based on market-orientation, scale, and production intensity into three major production systems: traditional smallholder, private/ stateowned commercial4, and urban/ peri-urban [6].

Smallholder and commercial dairy farms are emerging mainly in the urban and peri-urban areas are located near or in proximity of Addis Ababa and regional towns and take the advantage of the urban markets. Urban dairy production system includes specialized, state and businessmen owned farms, but owners have no access to grazing land [24-26] and most Regional towns and Woredas [27]. Urban milk system in Addis Ababa consists of 5167 small, medium and large dairy farms producing 34.65 million liters of milk annually. Of the total urban milk production, $73 \%$ is sold, $10 \%$ is left for household consumption, $9.4 \%$ is fed to calves (excluding the amount directly suckled by the calves) and $7.6 \%$ is processed into butter and cottage cheese. In terms of marketing, $71 \%$ of the producers sell milk directly to consumers and the rest reaches to the consumers through intermediaries.

Peri-urban milk production system possesses animal types ranging from $50 \%$ crosses to the high-grade Friesian in small to medium-sized farms. The peri-urban milk system includes smallholder and commercial dairy farm owners in the proximity of Addis Ababa and other Regional towns. This sector owns most of the country`s improved dairy stock. The main source of feed is both homes produced or purchased hay; and the primary objective is to get additional cash income from milk sale. This production system is now expanding in the highlands among mixed croplivestock farm owners such as those found in Selale and Holetta and serves as the major milk supplier to the urban market [28]. The rural system is non-market oriented and most of the milk produced in this system is retained for home consumption and usually marketed through the informal market after the households satisfy their needs.

\section{Milk Yield and Consumption Pattern}

Most dairy products in the world are consumed in the region or country in which they are produced because of milk and its various derivatives are highly perishable products [29]. The estimate of total cow milk production for the rural sedentary areas of Ethiopia is about 3.06 billion liters [5]. The average daily milk yield (DMY) performances of indigenous cows in PLWs was 1.85 litres/day and ranged from 1.24 liters in rural lowland agro-pastoral system of Mieso to 2.31 litres in rural highland dairy production system of Fogera [30]. For hybrid cows, milk production per day per cow of
8 to 10 liters while their hybrid cow's milk production per day is 11 to 15 liters [31]. In addition, the overall mean daily milk yield per liter per cow in western Oromiya were $2.2 \pm 0.6$ and $6.5 \pm 1.6$ for local and dairy breed [32]. Moreover, average daily milk yield of cross bred and local cows in Sululta were $9.56 \pm 3.010$ and $1.809 \pm 0.4574$ liter/day respectively. Moreover, the milk yield for crossbred and local cows in Wolmera areas were $8.60 \pm 2.703$ and $1.96 \pm 0.8193$ liters/day, respectively [33].

Currently Ethiopia's milk consumption is only 19 liters per person $10 \%$ of Sudan's and $20 \%$ of Kenya's - but urbanization is driving up consumption per capita consumption in Addis Ababa is 52 liters per person [34]. The average expenditure on milk and products by Ethiopian household's accounts for only $4 \%$ of the total household food budget. According to CSA [5] reported, from the total annual milk production, $42.38 \%$ used for household consumption, $6.12 \%$ sold, only $0.33 \%$ used for wages in kind and the rest $51.17 \%$ used for other purposes (could be to produce butter, cheese, and the likes). In rural area $59 \%$ and $41 \%$ of dairy farmers in Ada'a district, east Shawa zone sold raw milk through informal and formal milk marketing channels, respectively [35], but the finding of Valk \& Tessema [36] is $98 \%$ of milk produced in rural area sold through informal chain whereas only $2 \%$ of the milk produced reached the final consumers through formal chain. According to Geleti \& Eyassu $[37,38]$ reported, there is no well-organized milk marketing system in Nekemte and Bako milk shed, and Dire Dawa. Dairy co-operatives and milk groups have facilitated the participation of smallholders in fluid milk markets in the Ethiopian highlands.

In Ethiopia, most consumers prefer unprocessed fluid milk due to its natural flavor (high fat content), availability, taste and lower price. Milk consumption in Ethiopia shows that most consumers prefer purchasing of raw milk because of its natural flavor (high fat content), availability and lower price. Ethiopians consume fewer dairy products than other African countries and far less than the world consumption. The present national average capita consumption of milk is much lower, $19 \mathrm{~kg} /$ year as compared to $27 \mathrm{~kg}$ for other African countries and $100 \mathrm{~kg}$ to the world per capita consumption [39]. The recommended per capita milk consumption is $200 \mathrm{l} / \mathrm{y}$. The consumption in Addis Ababa is very high (51.85 litres) as compared to the national and other towns. Indian milk production grew by $4.5 \%$, Pakistan by $1.8 \%$, Germany by $1.2 \%$, and the USA by $1.1 \%$. Brazil's milk production decreased by $2.8 \%$ and New Zealand by $1.3 \%$ [40]. Generally, the demand for milk and milk products is higher in urban areas where there is high population pressure. The increasing trend of urbanization and population growth leads to the appearance and expansion of specialized medium-to-large scale dairy enterprises that collect, pasteurize, pack and distribute milk to consumers in different parts of the country [41].

Domestic and Export Market of Milk and Milk Product

Milk is channeled to consumers through formal and informal marketing systems [42]. The informal market involves direct 
delivery of milk by farmers to individual consumers in immediate neighborhood and sales to travelling traders or individuals in nearby towns. In informal market, milk may pass from producers to consumers directly or it may pass through two or more market agents. Ethiopia is not known to export dairy products; however, some insignificant quantities of milk and butter are exported to a few countries. Butter is mainly exported to Djibouti and South Africa (targeting the Ethiopians in Diaspora), while milk is solely exported to Somalia from the South Eastern Region of the country. As indicated by small quantities of cream are exported to Djibouti from Dire Dawa. The choice of targeting either domestic or export markets in the process of smallholder commercialization is basically linked to the nature of the targeted commodities [43]. For countries with large population size, domestic markets could also be a major market target due to higher domestic demand for both staples and high-value commodities [44]. In targeting the export market for the process of smallholder commercialization the issue of product quality, sanitary and phytosanitary standards, timely and regular supply, and volume need to be given emphasis in enabling the small-scale farmers to be part of the game [45].

The country spent over 678.75 million birrs to import various products of milk from 2006-2010. Expenditure on powdered milk accounted for $79.6 \%$, followed by cream, $12.9 \%$ and cheese $4.3 \%$ [46]. With Ethiopia already spending approximately $\$ 10$ million annually in foreign powdered milk imports, there is a huge opportunity for domestic UHT production to disrupt the current market. Investment size A \$10-11 million greenfield investment would create a UHT plant with the largest processing capacity in the Ethiopian market Capacity 10,000 liters/hour (80,000 liters/ day, 24 million liters/year employment 500-600 employees estimated return IRR of $25-35 \%$ over 5 years.

\section{International Market (Import Vs Export) in Milk and Milk Products}

Only about 66.5 million tons or $8.3 \%$ of total world dairy production is traded internationally, excluding intra-EU trade. Dairy trade volumes increased by 6\% from 2013 to 2014 compared to $2 \%$ growth between 2012 and 2013. International prices of all dairy products continued to decline from their 2013 peak for skim milk powder (SMP) and whole milk powder (WMP). A key factor was the decline in Chinese import demand, with demand for WMP dropping by 34\% from 2014 levels. This decrease in Chinese demand for dairy products was coupled with continued production growth between 2014 and 2015 in key export markets, with total output of milk increasing in Australia (4\%), European Union (2\%), New Zealand (5\%) and United States (1\%) [47]. At global level demand for milk and milk products in developing countries is growing with rising incomes, population growth, urbanization and changes in diets. This trend is pronounced in East and Southeast Asia, particularly in highly populated countries such as China, Indonesia and Vietnam. The growing demand for milk and milk products offers a good opportunity for producers (and other actors in the dairy chain) in high-potential, peri-urban areas to enhance their livelihoods through increased production.
Global milk production is estimated at approximately 735 billion litres annually.

General Agreement on Tariffs and Trade negotiations (GATT), followed by those of the world trade organization (WTO) changed in the sense of liberating trade from all public intervention. A structural change in the shape and form of the main exporters and importers has taken place on the international dairy scene following this freeing-up of the market. International trade in milk and dairy products has exhibited quite large fluctuations over the last few decades, resulting in changes to public policies in western countries and their decisions stop subsidizing products. Significant growth in exports as well as imports of fresh drinking milk (whole and/or skimmed), milk powder (whole and/or skimmed), condensed whole milk and evaporated milk between 1960 and 2010. The European Union accounts for the largest share in total volume of exported and imported milk, even though its average annual rate of growth over the 25 years studied was just $0.25 \%$. Worldwide new EU members, Oceania and Latin America have increased their share of total exported volumes. Milk production in 2015 was 6.4\% higher than in 2014. In 2015 South Africa imported $69354 \mathrm{t}$ of dairy products, up $72.5 \%$ on the same period the previous year, and exported $61296 \mathrm{t}$ of dairy products, $13.8 \%$ down on 2014. International dairy product prices continued the extreme volatility and downward trend experienced since 2014 [48].

Technological developments in refrigeration and transportation only $7 \%$ of the milk produced are traded internationally if intra-EU trade is excluded. Trade in dairy products is very volatile as dairy trade flows can be affected by overall economic a situation in a country fluctuation in supply and demand, changing exchange rates and political measures. With demand for dairy products most rapidly rising in regions that are not self-sufficient in milk production, volumes of dairy trade are growing. Also, the share of global dairy production that is traded will increase as trade will grow at a faster pace than milk production. The developed countries account for 62 percent of the world's dairy imports (measured in milk equivalents) and $93 \%$ of the exports, showing clearly that the major part of the global dairy trade takes place among developed countries [49].

\section{International trade requirements for dairy}

The international market for dairy products currently is far from having a single multinational processing firm [50]. Milk is perishable nature of dairy products, hygienic measures including heat treatment and cold storage are required to prevent hazardous bacterial contamination. By subjecting veterinary drugs and pesticides to strict authorization requirements, undesirable residue accumulation in dairy products is minimized. Other residues or contaminants, including diverse persistent environmental pollutants can accumulate in milk fat. Ensuring low levels of such pollutants in milk products requires adequate environmental protection. In the case of residues and contaminants that may constitute a danger to public health, regulations will set the maximum residue levels that are permitted in foodstuffs [51]. 
Especially in developing countries, but not exclusively there, it can be very difficult for farmers to meet private standards for milk quality and safety which might require investment in mechanical milking, on farm cooling, new feeds and genetic improvement. Apart from the initial investment cost a dairy farmer faces to meet those standards, also high operating costs might render small and even medium-scale units unprofitable in the long run.

There is different sanitary regulation apply both to dairy products and to the production processes. Regulation, which can be a mix of international recommendations and national legislation, is often dynamic. Regulation often is reactive: outbreaks of BSE in the UK and the associated fatalities of variant CJD in humans were followed by increased regulation of livestock products. In addition, rules develop in response to new scientific findings, albeit with a lag.

a. Sanitary product standards set targets for test results, and generally are composed of a maximum level of pathogenic load or contamination and the method for measurement. Micro bacterial standards apply to the dairy product as well as the raw milk inputs and are often measured by plate counts and cell counts. Tolerance levels also apply to contaminants such as residues of antibiotics or other veterinary medicine, mycotoxins and other 'natural' contaminants, or concentrations of food additives or pollution. Tolerances are set based on toxicological and epidemiological data that show effects on the health of humans and animals. The lower bound of a tolerance level is set by the limit of determination (LOD), which is the lowest possible concentration that can be picked up in a test. Due to the continuous progress of science and laboratory analyses, the LOD is continuously decreasing over time and moving ever closer to zero.

b. Process standards are used as a benchmark to judge whether a food has been produced in a manner to be fit for human consumption or trade. There are various required practices to ensure hygienic conditions of holdings and milk collection, processing plants, storage, and transport. Often, hygiene requirements demand a quality management scheme, such as hazard analysis critical control point (HACCP). A second important set of process standards applies to the health of the dairy cattle.

c. Conformity assessment is the provision of guarantees that the processes of hazard monitoring and control in the export firm are at least equivalent to those demanded by the importing country. The importing country has three mechanisms for enforcing that dairy shipments indeed meet its legal requirements: through certification, prior approval of handlers, and testing of the end-product.

\section{Development Policy and Strategy}

The current rural development policy and strategy of the country has some provisions indicating general direction for livestock development. Dairy Development Master Plan (DDMP) was formulated in 2002 to guide the sub-sector development and has been implemented since then across the regions. The DDMP highlights input and output targets but fails short of indicating roadmap and providing guidelines and principles to inform actual policy implementation on the ground. The uniqueness of each area means policy and development interventions must be customized. Whilst general guidelines and principles can be designed at national level, it is neither possible nor appropriate to design a master plan and implement throughout the country, or even throughout a province. Improving economic incentives to encourage innovations; pursuing value chain approach; providing public support to private sector development and private-public partnership; engaging in a holistic approach to technological innovations for increasing supply response; formulating policy and strategy to guide the sub-sector development, and strengthening capacity in local innovation systems with milk value chain perspective as strategic options for consideration by the relevant actors and stakeholders [52].

\section{Trends in Development of the Dairy Sector in Ethio- pia}

Global milk production has been strong over the last several years leading to expanded growth in trade in most years with a sudden drop off in 2015. For example, from 2005 to 2013, the world milk production increased more than $16 \%$ [53]. An average of 594.4 million metric tons of cow milk was produced throughout the world over the observed nine-year period. The six major milk suppliers, the EU-28, the US, India, China, Russia, and Brazil accounted for more than $80 \%$ of the world's cow milk production during the last four years EU-28 is the world's largest milk producer, the greatest growth in milk production among the top six milk suppliers occurred in India and China. India's cow milk production grew 15.3\% from 2012 to 2015, while China production expanded by $15.1 \%$ Brazil milk production grew by $14.3 \%$. Global dairy production is expected to continue to increase soon as world GDP raises and consumers' preferences for different types of dairy products expand.

\section{Opportunities and Challenges in Dairy Production Development in Ethiopia}

\section{Opportunities}

Ethiopia holds large potential for dairy development due to its large livestock population, urbanization, emerging middle class consumer segments that are willing to embrace new products and services, demand for and consumption of milk, positive economic outlook, livestock genetic resources and production system, expected to increase processed dairy products consumption favorable climate for improved, export and foreign market possibility (Somalia, Sudan, South Sudan and Djibouti are potential foreign markets), indigenous knowledge, income generation and employment, and the relatively disease-free environment for livestock. In addition, the purchasing power increase, population growth and consumer awareness will increase the demand for quality, volume, graded and standardized products and traceability of sources. Land O' Lakes in 2010 showed that the top $10 \%$ earners in Addis Ababa consumed about 38\% of milk, while the lowest income group, approximately $61 \%$ of the population consumed only $23 \%$. 


\section{Challenges}

In Ethiopian the major constraints for dairy sector are shortage of feed at the end of dry, land shortage for establish improved forage, genetic limitation, limited access and high cost of dairy heifers/cows absence of an operational breeding strategy and policy, inadequate veterinary service provision, weak linkages between research, extension service providers and technology users, inadequate extension and training service, milk market related constraints, reproductive problems, lack of research and information exchange system, lack of education and consultation, socio-economic challenges and limited availability of credit to the dairy farmer.

Dairy marketing is a key constraint to dairy development throughout Sub-Saharan Africa. Marketing problems must be addressed if dairying is to realize its full potential to provide food and stimulate broad based agriculture and economic development. Because dairy development is sources of employment since it is labor intensive and associated with large incomes and price elasticity of demand. There is also risk of price decrease to suppliers related to dairy imports and food aid, and seasonal fall in demand due to cultural conditions. Adulteration is also believed to be a problem especially among the smallholders. Therefore, to increase milk productivity, it is necessary to eliminate the limiting factors and in turn exploit opportunities that could improve productivity of milk [54].

\section{Major Trade Barriers to Dairy Products}

Milk and dairy products are considered high-risk goods in production, consumption and trade. The risks, or perceived risks, are that milk products pose threats to food safety and animal health. As a result, dairy trade is subject to a considerable amount of regulation to limit the transfer of risk. Whereas such sanitary measures are generally applied for legitimate reasons, they can also be used in a protectionist manner, and such tendencies might increase with the further lowering of tariffs and expansion of tariff rate quotas [55]. High tariffs effectively block certain markets for exports or place severe restrictions through limited levels of quota access, high trade restrictions, combined with domestic support for dairy production, are common in the largest dairy markets such as Canada, the US, the EU and Japan. These trade restrictions are a key reason why only $7 \%$ of global dairy production is traded. Trade in dairy is expected to increase due to the rising demand for dairy products in emerging and developing markets.

\section{Dairy Investment Policy Environment in Ethiopia (Figure 3)}

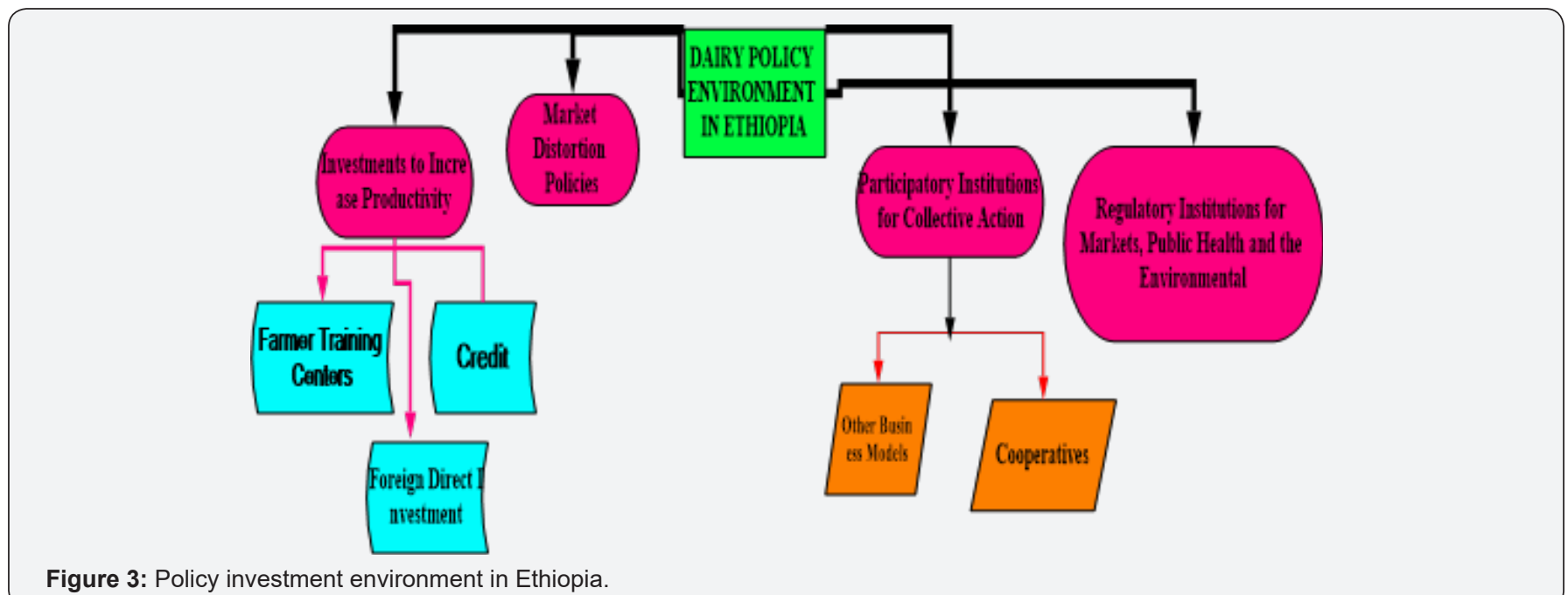

Figure 3: Policy investment environment in Ethiopia.

The policy and regulatory environment influenced the country's dairy sector characterized as free market economic system and the emergence of modern commercial dairying (1960 - 1974), socialist (Derg) regime that emphasized a centralized economic system and state farms (1974 - 1991) and free market and market liberalization (1991- present). The major goal of livestock policy programmed is to increase smallholders' returns from investments in animal agriculture by providing them with essential information on government policies in the sector and developing appropriate policy and institutional options that will help improve livestock productivity, asset accumulation, promote sustainable use of natural resources and building capacity of policy makers and analysts [56]. Investment in dairy cattle breeds improvement in the MRS system through crossbreeding using AI and synchronization. For the five-year GTP II period, a total investment of ETB 148 million is needed to improve the capacity of the AI centers and the related service, and the training of AI technicians. The investment by the GoE to put in place the AI and synchronization services for the intervention is only ETB 148 million (very good leveraging by the GoE). Average milk production per crossbred cow per day in small specialized dairy increases from 10 to 12 litres (20\% increase), in medium specialized dairy increases from 16 to 19.2 litres (20\% increase), in small specialized dairy units increases from 2593 to 2746 litres (6\% increase) and in medium specialized dairy units increases from 4608 to 5080 litres (10\% increase) are the improvement objective crossbred dairy cattle in specialized dairy with the adoption of the interventions during the GTP II [57].

To meet the targets projected for 2020 government policy 
is important to create an environment conducive for innovation and risk taking on the part of investors (Figure 4). Delgado [58] identify four policy pillars for commercialization of smallholder dairying

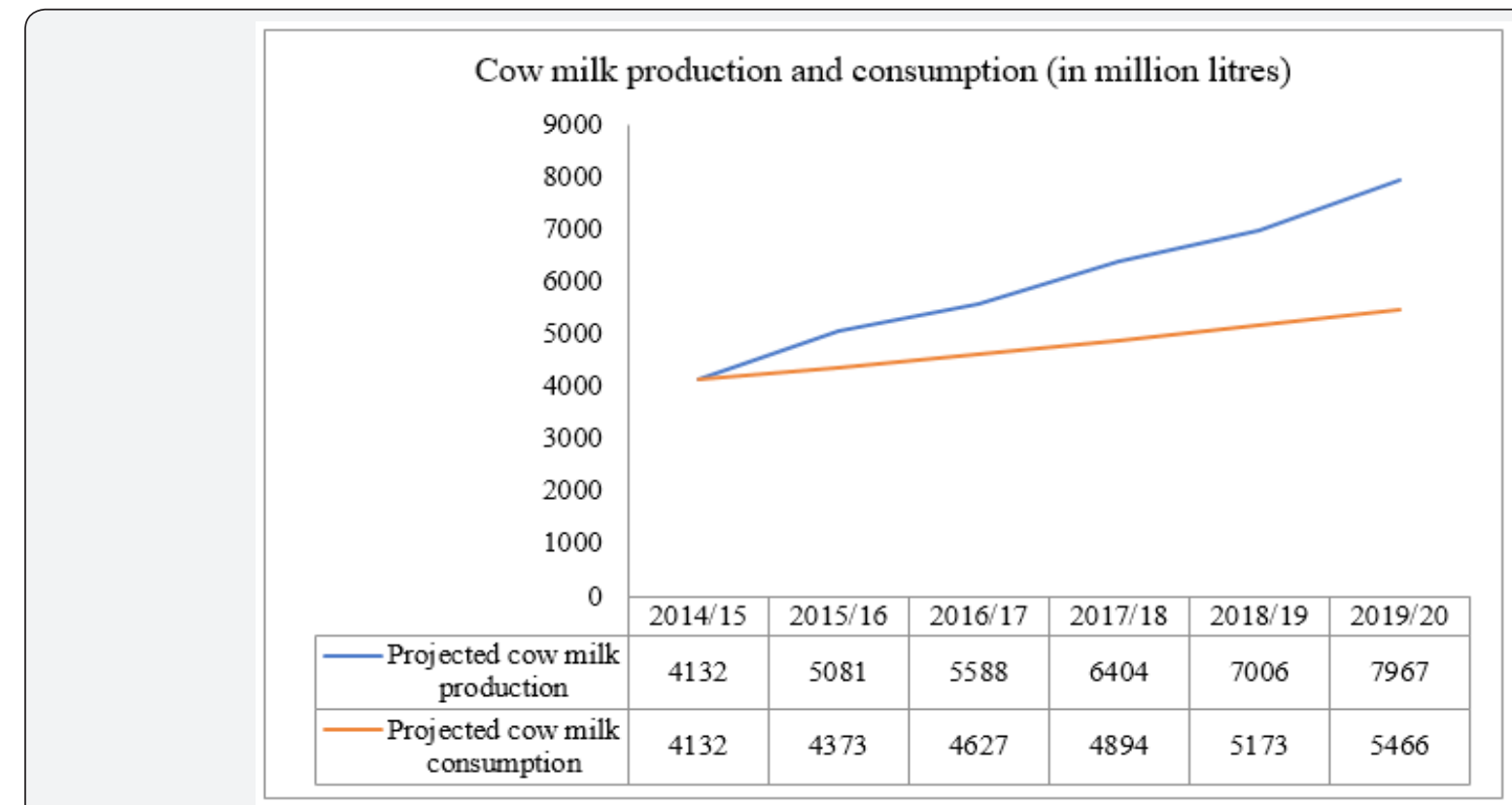

Figure 4: Projected cow milk production and consumption in 2020.

a. Remove market distortions

b. Building participatory institutions of collective actions by small producers to facilitate their vertical integration

c. Increasing investment to improve productivity

d. Promoting effective regulatory institutions to deal with public health and environmental concerns of livestock intensification.

\section{Current Scenario and Way Forward}

The prospects of dairying seem to bebrightbecausegovernment is attempting them remedy through policies and strategies. Thus, dairy farmers are on the way to getting access to services and inputs that could help promote dairy production and productivity. This mainly includes feed and feeding, breeding services, credit, extension, training, veterinary services, and appropriate marketing system that addresses consumers' demands etc. Since dairying is labor intensive, it promotes the motto of government policy in creating employment opportunities at house hold level. This improves employment, income and nutrition values of the family of the producers and the other demanders/consumers. The dairy industry would address and serve as one of the major instruments of the governments' policy in achieving food security. This in turn promotes dairy production due to the attention of given by the government [59-63]. According to the 2014 GDP per capita statistics $0.4 \%$ of the population has consumption of $10-20$ USD/day, $4.3 \%$ of the population $4-10$ USD/day and $24.6 \%$ of the population 2-4 USD/day per capita. With the increase in income, it is expected that consumption pattern shifts to high value food items that demands encouraging supply of livestock products. The contribution of medium specialized dairy to GDP increases from ETB 353 million in 2015 to ETB 751 million in 2020. Milk trade in the dry lands, which is concentrated near towns, there is greater involvement of poorer herders, especially women than there generally is for live animal trade. However, opportunities for dairy trade in the dry lands (especially commerce in cow milk and butter) are limited mainly to urban and peri-urban areas where consumers are available and distance to markets is minimal.

Livestock development is guided by the broad policies of the government. These include the Agriculture Development Led Industrialization (ADLI), Poverty Reduction Strategy Program (PRSP), Food Security Strategy (FSS), Rural Development Policy and Strategies (RDPS), Capacity Building Strategy and Program (CBSP), Agricultural Marketing Strategies (AMS), foreign affairs and security policy and strategy, the export strategy, and the draft livestock breeding policy [64].

A future milk surplus could be realized through investment in better genetics, feed and health services, improving both traditional dairy farms and commercial-scale specialized dairy production units. The investment interventions proposed to improve cattle milk production and the value chain would transform family dairy farms in the highland moisture enough production zone from traditional to market-oriented improved family dairy (IFD) systems. These proposed interventions would also vastly increase the commercial-scale specialized dairy units as well as improve milk production from indigenous (or local) cattle breeds. Dairy co-operatives and Milk groups have facilitated the participation of smallholder in fluid milk markets in the Ethiopian highlands. Milk groups are a simple example of an agro-industrial innovation, but they are only a necessary first step in the process of developing more sophisticated co-operative organizations and well-functioning dairy markets $[65,66]$. The survival of the milk 
groups that supply inputs and process and market dairy products will depend on their continued ability to capture value-added dairy processing and return that value-added to their members.

Evidence from Kenya emphasizes the importance of milk collection organizations in improving access to market and expanding productive bases. On the other hand, there is a need to stimulate consumption of dairy products in the country through various mechanisms, including school milk programmed as more consumption increase demand for dairy produce and can potentially encourage production in the long run. By increasing the number and productivity of cattle through improvements in genetics, health and feeding, domestic cow milk production will increase by about $93 \%$ by 2020 , consumption demand will be satisfied, and export of cow milk and milk products will begin.

The following points should be implemented to growth the dairy trade

a. A clear understanding of potential market trends and opportunities is needed for policy and planning in the dairy sub-sector.

b. Public policy-makers should engage constructively with traditional markets to link them with formal modern industry.

c. Make investment in dairy co-operative development effective and pro-poor should be well managed, placed outside strong political forces and linked to strong demand.

d. There must be a link between agricultural research and growth in dairy development. Investment in dairy development through provision of appropriate credit and research technologies to smallholder producers will bring growth and shift producers towards greater commercial orientation, increasing their demand for improved technologies and innovations [67].

e. Imports and exports as well as macro policy and level of openness of the economy, can play a consistent role in the pace of dairy sector development. Import controls/ restrictions which is not for purposes of enforcing Sanitary Requirements and Food Safety Standards should be reduced or abolished. By so doing the role of domestic market protection will be relegated to ratification of dairy products.

f. Ethiopia dairy industry currently lacks some categories of products in terms of variety, quality and quantity. These include; cheeses, butter, milk powder, whey, yoghurts and ice cream. The processors can seek ways to increase capacity and invest aggressively in product development.

g. The performance of the few milk producing co-operatives operating so far has shown that the quantity of locally produced milk currently available to processors and consumers could be increased significantly if effective collection (quality controlplatform, chemical and microbiological) tests, transportation, cooling and marketing systems are put in place.

h. Milk producers' organizations should provide 'support services' to increase clean milk production. An effective and well-trained animal health service should be available at any time to look after the health of animals, arrangements should be made for regular vaccination and checking against contagious diseases by the qualified veterinarians.

i. Formation of Dairy Board at national level and regional level are important for the development of the dairy industry [68]. Introduction of programs that will increase milk consumption (e.g. introduction of school milk program) price differentiation (i.e. premium price for high quality milk) are important for increasing milk production and consumption.

j. Addressing milk quality concerns and transforming the informal milk markets based on the concept of business development services (BDS), and be supervised by national regulatory authorities

k. As in many African countries, knowledge of hygiene is often not enough. Thus, the most important support services regarding clean milk production is "Extension -Education".

\section{Conclusion and Recommendation}

\section{Conclusion}

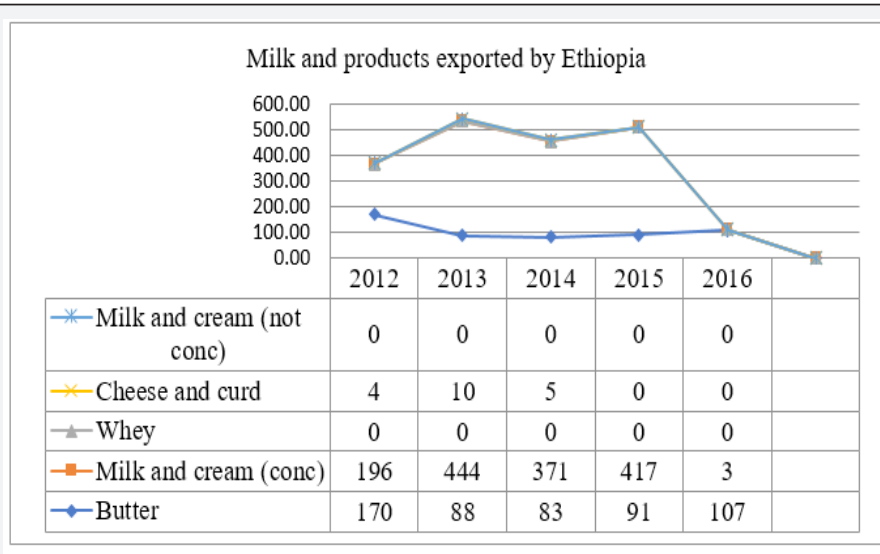

Figure 5: Milk and milk products exported by Ethiopia from 2012-2016. 


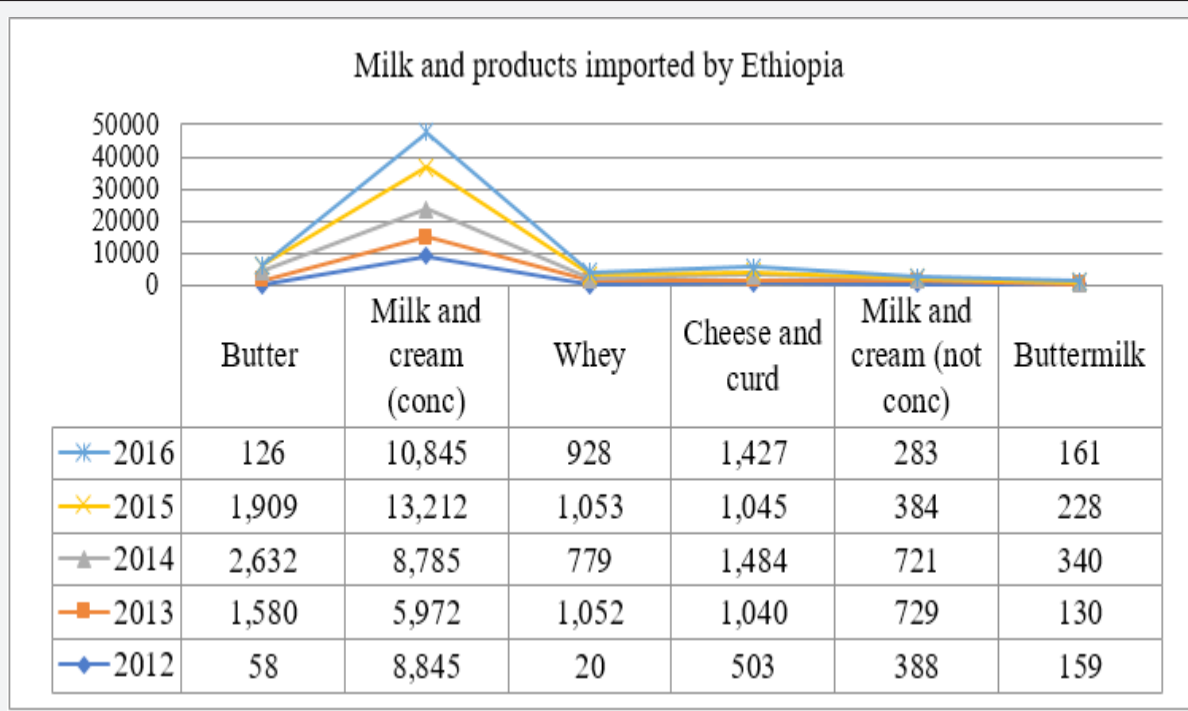

Figure 6: Milk and milk products imported by Ethiopia from 2012-2016.

Only about 66.5 million tons or $8.3 \%$ of total world dairy production is traded internationally, excluding intra-EU trade. Even if the demand is estimated 15 million tons of product annually, 816.0 million tons milk produced and the traded was 73.2 million tons. Over the last decade interest in global dairy trade has intensified partially because of the enormous impact that domestic and international policies have had or are projected to have on the global trade and domestic supply. In 2012-2016 Ethiopia imported more milk and milk products than exported (Figures 5 \& 6). Though dairy sector in Ethiopia has a challenge, there are potential to development. Imports and exports as well as macro policy and level of openness of the economy, can play a consistent role in the pace of dairy sector development.

\section{Recommendation}

a. Should be develop marketing channels which can be used to promote the milk producers and dairy value chain actors, aware of the potential for increased production and marketing of specific products

b. Should be encourage licensed traders and qualitybased payments, strengthen the coordination between union, primary cooperatives and farmers and improve the effectiveness

c. Improve HACCP knowledge and skills and ensure milk producers, processors, transporters, retainers and collectors.

d. Dairy plants (like collection center, bulk cooling, transport, processing and distribution) should be organized to enhance formal marketing/trade

e. Should be set a clear market trends and opportunities policy and planning in the dairy sector

f. Strengthen investment in dairy co-operative development effective and pro-poor should be well managed, placed outside strong political forces and linked to strong demand g. Should be encourage/develop quality control to increase consumer knowledge and demand for specific products

h. Improve milk production efficiency can be important through specific education and training

i. Improve milk production efficiency by investing high dairy herd size and create free access for investors in larger dairy farms with the best growth potential of livestock selection service recording system and strengthening project which supports investment and training in commercial dairy farms.

j. Training should be provide by professional for producers, dairy value chain actors, may include: skills and know-how on marketing and branding products to identify new opportunities at the dairy processing level; support for research and development initiatives for new dairy products; case studies and exposure to foreign experiences might stimulate creativity and entrepreneurship at the dairy processing level; a better understanding and a greater focus on market-driven value chains; knowledge of the requirements of food retailers is a precondition for the successful marketing of their products, better knowledge about these requirements may lead to opportunities for increased market participation; developing intermediary support structures that bring buyers and suppliers together is another initiative that can be undertaken at local and national levels.

k. Should be build the trust within farm communities and to improve awareness of the benefits of a more cooperative approach in terms of bargaining power and marketing strategy.

l. Develop or improve the image of the dairy sector by professionalizing the sector, to create better-quality jobs for young, well-educated people, and professional farms and a better marketing strategy for adding value, higher incomes and a more attractive dairy sector. More emphasis must be 
placed on a young and successful entrepreneur profile to attract young people to the sector

Government should be fund for milk producers and investors based on their project proposal

\section{References}

1. Achterbosch T (2007) Between Safety and Commerce: How Sanitary Measures Affect Global Dairy Trade. International Food \& Agricultural Trade Policy Council.

2. Ahmed MM, Ehui S, Yemesrach A (2003) Dairy development in Ethiopia. Paper presented at the success in African Agriculture Conference In: Went, IFPRI, NEPAP, CTA conference paper. No. 6.1-3 December 2003, Pretoria, South Africa.

3. Aklilu Y, Little PD, Mahmoud H, McPeak J (2013) Market access and trade issues affecting the drylands in the Horn of Africa. Brief prepared by a Technical Consortium hosted by CGIAR in partnership with the FAO Investment Centre. Technical Consortium Brief 2. Nairobi: International Livestock Research Institute, Ethiopia.

4. Amha Kasahun (2008) An Integrated Urban, Peri-Urban and Rural Dairy Development Program in Tigray. Draft Document Livestock Development Consulting Group. REST, Mekelle, Ethiopia.

5. CSA (2016) Federal Democratic Republic of Ethiopia. Agricultural sample survey. Livestock and livestock characteristics (private peasant holdings), Volume II. Addis Ababa, Ethiopia.

6. SNV (Netherlands Development Organization) (2008) Study on Dairy Investment Opportunities in Ethiopia. Addis Ababa, Ethiopia.

7. Solomon Mekuria (2016) Smallholder dairy farm management in Ethiopia: Status in Hawassa and Debrebrihan Cities. J Veterinary Sci Technol 7: 306.

8. Asrat A, Feleke A, Ermias B (2016) Characterization of Dairy Cattle Production Systems in and around Wolaita Sodo Town, Southern Ethiopia. Scholarly Journal of Agricultural Science 6(3): 62-70.

9. Tsehay Redda (2001) Small-scale milk marketing and processing in Ethiopia. In: Rangnekar D and Thorpe W (Eds.), Smallholder dairy production and marketing opportunities and constraints. Proceedings of a South-South workshop held at NDDB, Anand, India, and 13-16.

10. Holloway G, Ehui S (2002) Expanding market participation among smallholder livestock producers: A collection of studies employing Gibbs sampling and data from the Ethiopian International Livestock Research Institute, 2005-2007. Medium-term plan. Livestock: A pathway out of poverty.

11. IDF (2015) The World Dairy Situation. Bulletin of the International Dairy Federation.

12. Davis CG, Hahn W (2016) Assessing the status of the global dairy trade. International Food and Agribusiness Management 19: B.

13. WTO (World Trade Organization) (2016) The WTO Agreement on the Application of Sanitary and Phytosanitary Measure.

14. TAP (2016) Value chain study on dairy industry in Ethiopia. Addis Ababa chamber of commerce and sectoral associations.

15. Feleke Getachew (2003) Milk and Dairy Products, Post-harvest Losses and Food Safety in Sub-Saharan Africa and the Near East. A Review of the Small-Scale Dairy Sector-Ethiopia. FAO Prevention of Food Losses Programme. FAO, Rome, Italy.

16. Ketema H (2000) Dairy development in Ethiopia the role of village dairy co-operatives in dairy development. Smallholder Dairy Development Project Ministry of Agriculture Addis Ababa, Ethiopia p. 26-39.

17. Zegeye Yigezu (2000) DDE's Experience in Milk Collection, Processing and Marketing: In: Proceedings of the Role of Village Dairy CoOperatives in Dairy Development." Smallholder Dairy Development
Project (SDDP), (MOA) Ministry of Agriculture, Addis Ababa, Ethiopia p. 49-58.

18. Staal SJ (1995) Peri-urban dairying and public policies in Ethiopia and Kenya: A comparative economic and institutional analysis. Dept of Food and Resources Economics, Univ. of Florida, Gainesville, Florida, USA.

19. Workneh Abebe, Ponnusamy K (2016) Determinants of Improved Dairy Practices Adoption in West Shewa Zone of Oromia, Ethiopia. Indian Res. J Ext Edu 16: 3.

20. Dereje T, Workneh A, Hegde BP (2005) Survey of traditional cattle production systems and preferred cattle functions in North and South Wollo Zones, Ethiopia. Ethiopian Veterinary Journal, 9: 91-108.

21. Sintayehu Yigrem, Fekadu Beyene, Azage Tegegne, Berhanu Gebremedhin (2008) Dairy production, processing and marketing systems of Shashemene-Dilla area, South Ethiopia. IPMS (Improving Productivity and Market Success) of Ethiopian Farmers Project Working Paper 9. ILRI (International Livestock Research Institute), Nairobi, Kenya, p. 62.

22. Asrat A, Zelalem Y, Ajebu N (2013) Characterization of milk production systems in and around Boditti, South Ethiopia. Int. J Irrd 25: 10.

23. Yoseph Mekasha, Azage Tegegne, Alemu Yami, Umunna NN (2003) Evaluation of the General farm characteristics and dairy herd structure in urban and peri-urban dairy production systems in Addis Ababa Milk Shed. In: Yilma Jobre and Getachew Gebru (Eds.), Proceedings of the 10th annual conference of the Ethiopian society of animal production, Addis Ababa, Ethiopia, August 21(23): 139-144.

24. Felleke Getachew, Gashaw Geda (2001) The Ethiopian dairy development policy: a draft policy document. Ministry of agriculture (MoA), Addis Ababa, Ethiopia.

25. Azage Tegegne (2003) Financing market-oriented milk developmentthe case of Ada'a-Liben district milk and milk products marketing association, Ethiopia. Urban Agriculture Magazine 9: 25-27.

26. Yitaye Alemayehu M, Wurzinger Azage Tegegne, Zollitsch W (2009) Handling, processing and marketing of milk in the North western Ethiopian highlands. Livestock Research for Rural Development 21: 97

27. Negussie E, Brannang E, Banjaw K, Rottmann OU (1998) Reproductive performance of dairy cattle at Assella livestock farm. Arsi. Ethiopia. I: Indigenous cows versus their F1 crosses. Journal of Animal Breeding and Genetics 115: 267-2800ctober 8 to 10, 2008. Part ii technical session. ESAP, AddisAbaba pp. 32.

28. Gebre Wold A, Alemayehu M, Demeke S, Bediye S, Tadesse A (2000) Status of dairy development. Smallholder Dairy Development Project (SDDP) dairy research in Ethiopia. In: The role of village dairy co-operatives in dairy development. SDDP (Smallholder Dairy Development Project) Proceedings, MOA (Ministry of Agriculture), Addis Ababa, Ethiopia.

29. Shadbolt NM, Apparao D (2016) Factors Influencing the Dairy Trade from New Zealand. International Food and Agribusiness Management Review p. 19.

30. Azage Tegegne, Berhanu Gebremedhin, Dirk Hoekstra, Berhanu Belay, Yoseph Mekasha (2013) Smallholder dairy production and marketing systems in Ethiopia: IPMS experiences and opportunities for marketoriented development. IPMS (Improving Productivity and Market Success) of Ethiopian Farmers Project Working Paper 31. ILRI, Nairobi, Kenya.

31. Tadesse Kenea, Girma Gebresenbet, David Ljungberg (2015) Characterizing Milk Supply and Marketing Chains and Losses in Wolmera and Ejere Districts of Ethiopia. Journal of Service Science and Management p. 8.

32. Ulfina Galmessa, Jiregna Dessalegn, Alganesh Tola S Prasad, Mulugeta Kebede (2013) Dairy Production Potential and Challenges in Western Oromia Milk Value Chain, Oromia, Ethiopia. Journal of Agriculture and Sustainability 2(1): 10-13. 
33. Mustefa Abu (2012) Value Chain and Quality of Milk in Sululta and Welmera Weredas, Oromia Special Zone Surrounding Addis Ababa, Oromia, Ethiopia. Addis Ababa University, Debre Zeit, Ethiopia. Msc. Thesis, p. 36-42.

34. ATA (Agricultural Transformation Agency) (2016) Promising investment opportunities in Ethiopian agribusiness. WEF Grow Africa, Ethiopia.

35. Girma Debele, Verschuur M (2014) Assessment of factors and factors affecting milk value chain in smallholder dairy farmers: A case study of Ada'a District, East Shawa Zone of Oromia regional State. Ethiopia African Journal of Agricultural Research 9(3): 345-352.

36. Valk VO, Tessama A (2010) The formal dairy chain of Addis Ababa, an analysis of the integration of small -scale dairy farmers in Ethiopian, Addis Ababa, Ethiopia.

37. Geleti D, Hailemariam M, Mengistu A, Tolera A (2014) Analysis of fluid milk value chains at two peri-urban sites in western Oromia, Ethiopia: Current status and suggestions on how they might evolve. Global Vet 12(1): 104-120.

38. Eyassu Seifu, Doluschitz R (2014) Analysis of the dairy value chain: Challenges and opportunities for dairy development in Dire Dawa, Eastern Ethiopia. International Journal of Agricultural Policy and Research 2(6): 224-233.

39. FAO (2003) World Agriculture: Towards 2015/1030. A FAO Perspective. Bruinsma J (Eds.), Food and Agricultural Organization of the United Nations, Rome, Italy and London, Earthscan, London, UK.

40. Lactodata (2016) Statistics A Milk SA publication compiled by the Milk Producers organisation 19:1.

41. Zelalem Yilma, Guernebleich E, Ameha Sebsibe (2011) A review of the Ethiopian dairy sector. Addis Ababa, Ethiopia: FAO Sub Regional Office for Eastern Africa (FAO/SFE).

42. Holloway G, Nicholson C, Delgado C, Staal S, Ehui S (2000) Agro industrialization through institutional Innovation: Transaction costs, Cooperatives and Milk- Market Development in The East-African Highlands. Agricultural Economics 23: 279-288.

43. SNV (2006) Developing a Market Led Strategy for the Ethiopian Dairy Industry, by Technoserve Kenya, Nairobi, Kenya, p. 43.

44. Moti Jaleta, Berhanu Gebremedhin, Hoekstra D (2009) Smallholder commercialization: Processes, determinants and impact. Discussion Paper No. 18. Improving Productivity and Market Success (IPMS) of Ethiopian Farmers Project, ILRI (International Livestock Research Institute), Nairobi, Kenya. P. 55.

45. Henson S, Loader R, Swinbank A, Bredahl S (1999) The impacts of sanitary and phytosanitary measures on developing country exports of agricultural and food products. The World Bank and WTO, Geneva.

46. MoA, ILRI (2013) Dairy value chain vision and strategy for Ethiopia. Addis Ababa, Ethiopia: Ministry of Agriculture and International Livestock Research Institute.

47. OECD/FAO (2016) OECD-FAO Agricultural Outlook, OECD Publishing, Paris, France.

48. Lactodata (2015) Statistics A Milk SA publication compiled by the Milk Producers organisation 19: 1 .

49. Knips V (2005) Developing Countries and the Global Dairy Sector Part I Global Overview. Pro-Poor Livestock Policy Initiative.

50. Emayenesh Seyoum E, Goddard D, Mac Laren, Griffith (2003) International Trade. In: Dairy Products: Processors Market Power. $47^{\text {th }}$ Annual Conference of the Australian Agricultural and Resource Economics Society.

51. Rikilt (2005) Residue monitoring in The Netherlands 1998 Programme for the Quality of Agricultural Products. Updated to 2005. Wageningen: Rikilt - Institute of Food Safety.

52. Tesfaye Lemma, Azage Tegegne R. Puskur, Hoekstra D (2008) Moving Ethiopian smallholder dairy along a sustainable commercialization path: missing links in the innovation systems. IN: Smallholder dairy production in Ethiopia: challenges and prospects. Proceedings of a workshop jointly organized by SIDA/SAREC and Faculty of Veterinary Medicine, Addis Ababa University, Adama, Ethiopia.

53. FAO (2015) Milk Whole Fresh Cow.

54. Brokken F Ray, Senait Seyoum (2006) Dairy Marketing in Sub-Saharan Africa. ILCA, Addis Ababa, Ethiopia.

55. IDF (2000) Overcoming barriers to world trade in food and dairy products. In: IDF Bulletin of the International Dairy Federation.

56. Ehui SK, Ahmed MM, Berhanu Gebremedhin, Benin SE, Nin-Pratt A, et al. (2003) 10 years of Livestock Policy Analysis. Policies for improving productivity, competitiveness and sustainable livelihoods of smallholder livestock producers. ILRI (International Livestock Research Institute), Nairobi, Kenya pp. 118.

57. Shapiro BI, Gebru G, Desta S, Negassa A, Nigussie K, et al. (2015) Ethiopia livestock master plan. ILRI Project Report. Nairobi, Kenya: International Livestock Research Institute (ILRI).

58. Delgado C, Rosengrant M, Steinfeld H, Ehui S (1999) Livestock to 2020: The Next Food Revolution. Food, Agriculture, and the Environment Discussion Paper 28, IFPRI, FAO, and ILRI.

59. Tsehay R (1997) Milk processing and marketing options for rural small scale producers.bIn: proceedings of the $5^{\text {th }}$ National conference of ESAP, Addis Ababa, Ethiopia p: 61-71.

60. CPPMU (Central Planning and Project Monitoring Unit) (2015) Ministry of Agriculture, Livestock and Fisheries. Economic Review of Agriculture (ERA), republic of Kenya, p. 95.

61. FAO (2016) Food and Agriculture Organization of the United Nations.

62. FAOSTAT (2017) Food and Agricultural Organization of the United Stations. Statistics Division.

63. Hall A, Mytelka L, Oyeyinka B (2006) Concepts and guidelines for diagnostic assessments of agricultural innovation capacity. United Nations University-Maastricht Economic and Social Research and Training Centre on Innovation and Technology Working Paper, Ethiopia.

64. IDF (International Dairy Federation) (2016) The world dairy situation. Bulletin of the International Dairy Federation 485/2016

65. IFCN (2016) International Farm Comparison Network.

66. Land 0 Lakes (2010) The next stage in dairy development for Ethiopia: Dairy value chains, end markets and food security. Addis Ababa, Land O Lakes Inc, Ethiopia.

67. Mesay Yami, Bedada Begna, Teklemedihin Teklewold (2013) Enhancing the productivity of livestock production in highland of Ethiopia: Implication for improved on-farm feeding strategies and utilization. African Journal of Water Conservation and Sustainability 1: 1529.

68. Vitaliano P (2016) Global Dairy Trade: Where are We, How Did We Get Here and Where are We Going? International Food and Agribusiness Management Review 26(2): 249-260. 
This work is licensed under Creative Commons Attribution 4.0 License DOI: 10.19080/JDVS.2018.08.555728
Your next submission with Juniper Publishers will reach you the below assets

- Quality Editorial service

- Swift Peer Review

- Reprints availability

- E-prints Service

- Manuscript Podcast for convenient understanding

- Global attainment for your research

- Manuscript accessibility in different formats ( Pdf, E-pub, Full Text, Audio)

- Unceasing customer service

Track the below URL for one-step submission https://juniperpublishers.com/online-submission.php 